\title{
ALK negative anaplastic large cell lymphoma of the oral cavity showing spontaneous regression
}

\author{
Sarah G Fitzpatrick ${ }^{1}$, Leah M Bowers ${ }^{2}$, Samer Z Al-Quran ${ }^{3}$, Eric G Fox ${ }^{4}$, Donald M Cohen ${ }^{2}$, \\ Indraneel Bhattacharyya ${ }^{2}$ \\ 1. Department of Oral Pathology, Case Western Reserve University College of Dental Medicine, Cleveland OH 2. University \\ of Florida College of Dentistry, Department of Oral and Maxillofacial Diagnostic Sciences, USA 3. University of Florida \\ College of Medicine, Department of Pathology, USA 4. Private Practice, Coral Springs FL, USA.
}

Correspondence: Indraneel Bhattacharyya. Address: Division of Oral Pathology, Department of Oral and Maxillofacial Diagnostic Sciences, University of Florida College of Dentistry, PO Box 100414 JHMHC, Gainesville, FL, USA. Telephone: 352-273-6689. Fax: 352-294-5310. E-mail: ibhattacharyya@dental.ufl.edu

Received: March 5, 2012

DOI : $10.5430 /$ jhm.v2n2p49
Accepted: April 19, 2012

URL: http://dx.doi.org/10.5430/jhm.v2n2p49
Published: June 1, 2012

\begin{abstract}
Anaplastic large cell lymphoma is a subset of T-cell lymphoma which is rarely seen in the oral cavity. This entity may be either primary cutaneous or systemic and the prognosis varies significantly by subtype. In addition, several similar entities have been reported which may mimic this lesion both clinically and histologically. We present a case of anaplastic large cell lymphoma, ALK negative, on the mucosal aspect of the upper lip of an 88 year-old female with a history of cutaneous T-cell lymphoma which demonstrated spontaneous regression after biopsy. A brief review of the literature along with an overview of clinical behavior, histologic presentation, immunohistochemical analysis, genetics, and differential diagnosis of this subtype of anaplastic large cell lymphoma are presented.
\end{abstract}

\section{Key words}

Anaplastic large cell lymphoma, Oral cavity, CD30+

\section{Introduction}

Anaplastic large cell lymphoma (ALCL) is a rare subtype of T-cell lymphoma that can involve mucocutaneous sites primarily or secondarily as part of systemic disease. ALCL is usually comprised of large atypical lymphoid cells with abundant cytoplasm and pleomorphic, often kidney shaped nuclei (Hallmark cells). In all cases, these cells are CD30 (Also known as Ki-1) ${ }^{[1]}$. positive and most cases they express cytotoxic granule-associated protein (Perforin, TIA-1 and granzyme B). A significant percentage of ALCL harbors the $\mathrm{t}(2 ; 5)(\mathrm{p} 23 ; \mathrm{q} 35)$ translocation. Based on the expression of the resulting gene product: Anaplastic lymphoma kinase (ALK), ALCL can be further subdivided into ALK (+), more common in the first three decades of life, and ALK (-) categories. The ALK (-) ALCL is more heterogeneous subgroup with more variations in morphology and immunophenotype, and worse clinical outcome. Systemic ALCL must be differentiated from primary cutaneous type of ALCL and from other subtypes of CD30 (+) lymphomas with anaplastic features ${ }^{[2]}$. Significant differences in behavior and prognosis exist between the different subtypes ${ }^{[1]}$. ALCLs comprise only $2.4 \%$ of head and neck lymphomas ${ }^{[3]}$. 
Oral manifestations of T-cell lymphomas are very rare; $92 \%$ of lymphomas in the oral cavity are of B cell lineage, most frequently diffuse large B-cell lymphomas (DLBCL) ${ }^{[3]}$. The majority of cases of cutaneous T-cell lymphoma involving the oral cavity represented cases of mycosis fungoides ${ }^{[4]}$. We present a patient with a history of primary T-cell lymphoma of the skin who developed oral lesions consistent with ALCL. Several previously reported cases of ALCL involving the oral cavity are presented along with a discussion of the spectrum of this disorder and other similarly-presenting ulcerating oral lymphoproliferative disorders.

\section{Case report}

An 88 year-old female presented to an oral surgeon (E.F.) with a non-healing, rapidly enlarging, ulcerated lesion measuring 2.5 by $1.0 \mathrm{~cm}$ on the labial mucosa of the right upper lip (Figure 1). The lesion had previously been treated with antibiotics without improvement. Her medical history included cutaneous T-cell lymphoma diagnosed 4 years previously with lesions on the right flank of the abdomen confirmed by biopsy and T-cell gene rearrangement study. After the initial excisions, no further cutaneous lymphoma lesions had developed in the intervening period. Her medical history also included a previous CVA and bladder cancer. She reported no history of tobacco or alcohol use. At the time of her clinical presentation, she denied fever, night sweats, or difficulty swallowing. No lymphadenopathy was noted at her clinical examination. Results of laboratory testing at this time revealed hemoglobin, hematocrit, white blood cell and platelet counts all within a normal range.

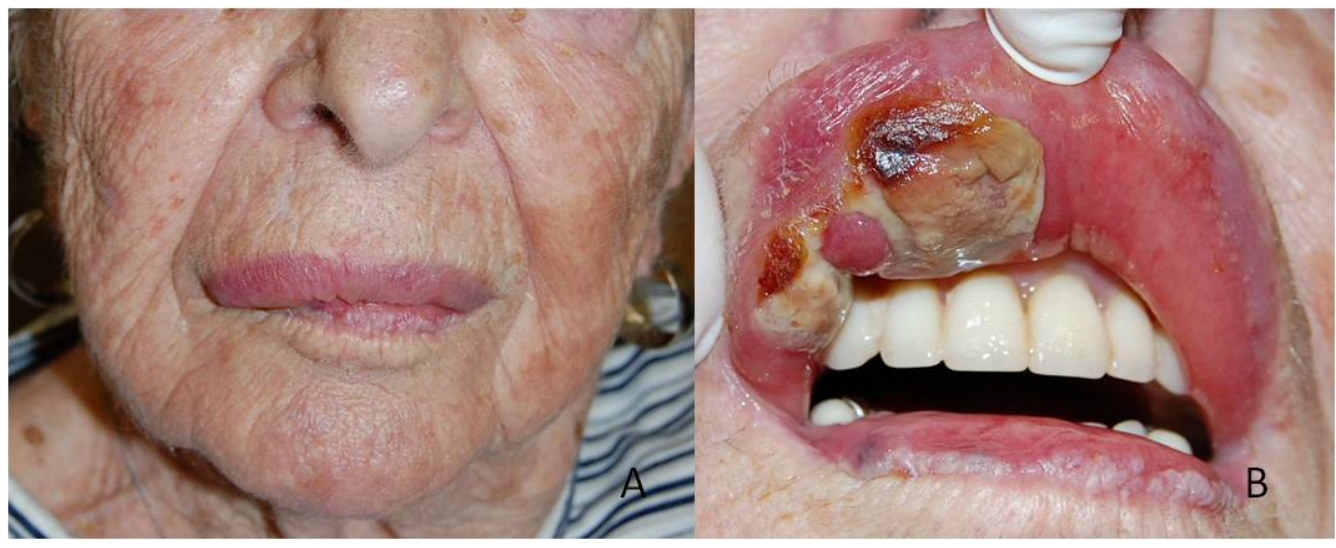

Figure 1. A. Initial presentation showing swelling of the upper lip. B. Rapidly growing ulcerated and necrotic lesion of the mucosal aspect of the upper lip

An incisional biopsy of the labial mucosa lesion was submitted for pathologic examination. Examination of histologic sections from this lesion revealed an atypical lymphocytic infiltrate consisting of large, lymphoid cells with large pleomorphic nuclei, numerous atypical mitoses, large zones of necrosis with surface ulceration and an infiltrative pattern. A mixed inflammatory background was noted with a large number of eosinophils along with granulocytes, histiocytes, small lymphocytes and some plasma cells (Figure 2 A-C). Occasional large atypical mononuclear Reed-Sternberg-like cells were also seen. Immunohistochemical studies (Table 1) performed with appropriate positive and negative controls (Figure 2D-I) revealed that the neoplastic cells were strongly CD30 (+), with membranous and Golgi pattern of expression, CD3 (-), strongly CD8 (+), CD7 (-), ALK1 (-), CD56 (-) and performing (-) with variable immunoreactivity for CD4 and CD45 and focal weak immunoreactivity for CD5. They were also negative for B-cell markers (CD20, CD79a, OCT2, and PAX5). CD15 and EMA were negative as well. In situ hybridization study for EBV encoded RNA (EBER) was negative. Immunohistochemistry for Ki-67 showed frequent labeling of nuclei (Approximately $50 \%$ of the lesional cells). Few reactive T cells were noted in the background. A diagnosis of ALK- anaplastic large cell lymphoma was made. 

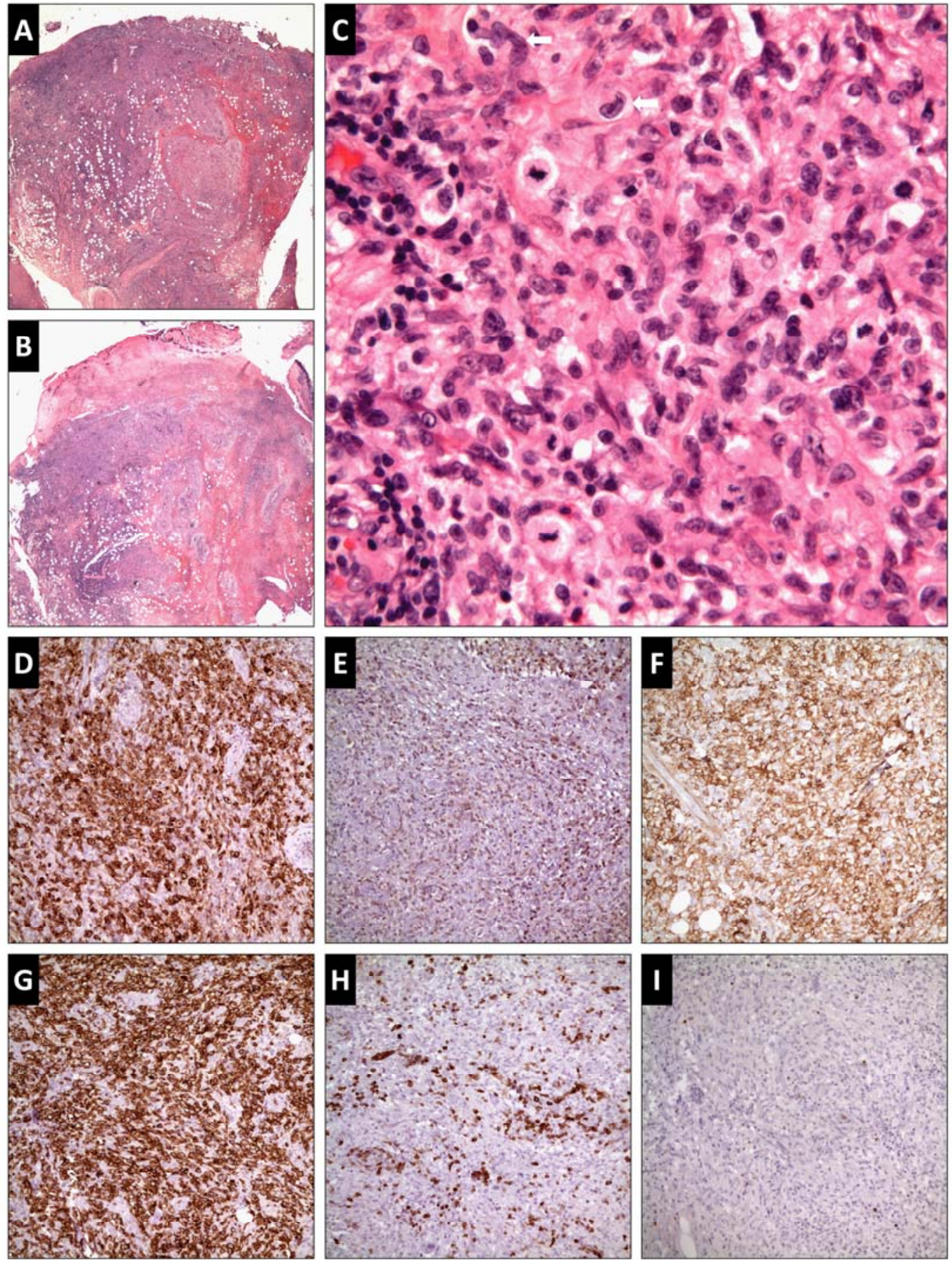

Figure 2. Composite photomicrograph showing the morphologic features of this case of ALK (-) anaplastic large cell lymphoma and the immunohistochemical profile. Low power view showing a very dense and deep lymphocytic infiltrate (A) with necrosis and surface ulceration (B) (Hematoxylin and eosin stain, magnification original X 20). Higher power view (C) shows an abnormal infiltrate of large atypical lymphocytes with pleomorphic nuclei, including Hallmark cells with horseshoe- or kidney-shaped nuclei (arrows). There is a brisk mitotic activity (Hematoxylin and eosin stain, magnification original X 500. Immunohistochemical studies (D-I, original magnification X 200) show that the neoplastic cells are strongly CD30 positive (D) with membranous and Golgi-type staining, CD3 negative (E), variably CD4 positive (F), which also highlights some histiocytes in the background, strongly CD8 positve (G), CD7 negative (E), note the presence of few reactive CD7 (+) small T cells in the background, and Perforin negative (I) 
Two weeks post biopsy, the patient returned to her oral surgeon with the lesion significantly reduced in size (Figure 3). She then had PET scan for staging and to rule out the presence of systemic disease, but the results were unavailable. No skin lesions or systemic signs and symptoms were reported by the patient. A plan was made for local radiation therapy to the mucosal lesion. She was lost to follow-up at this point.

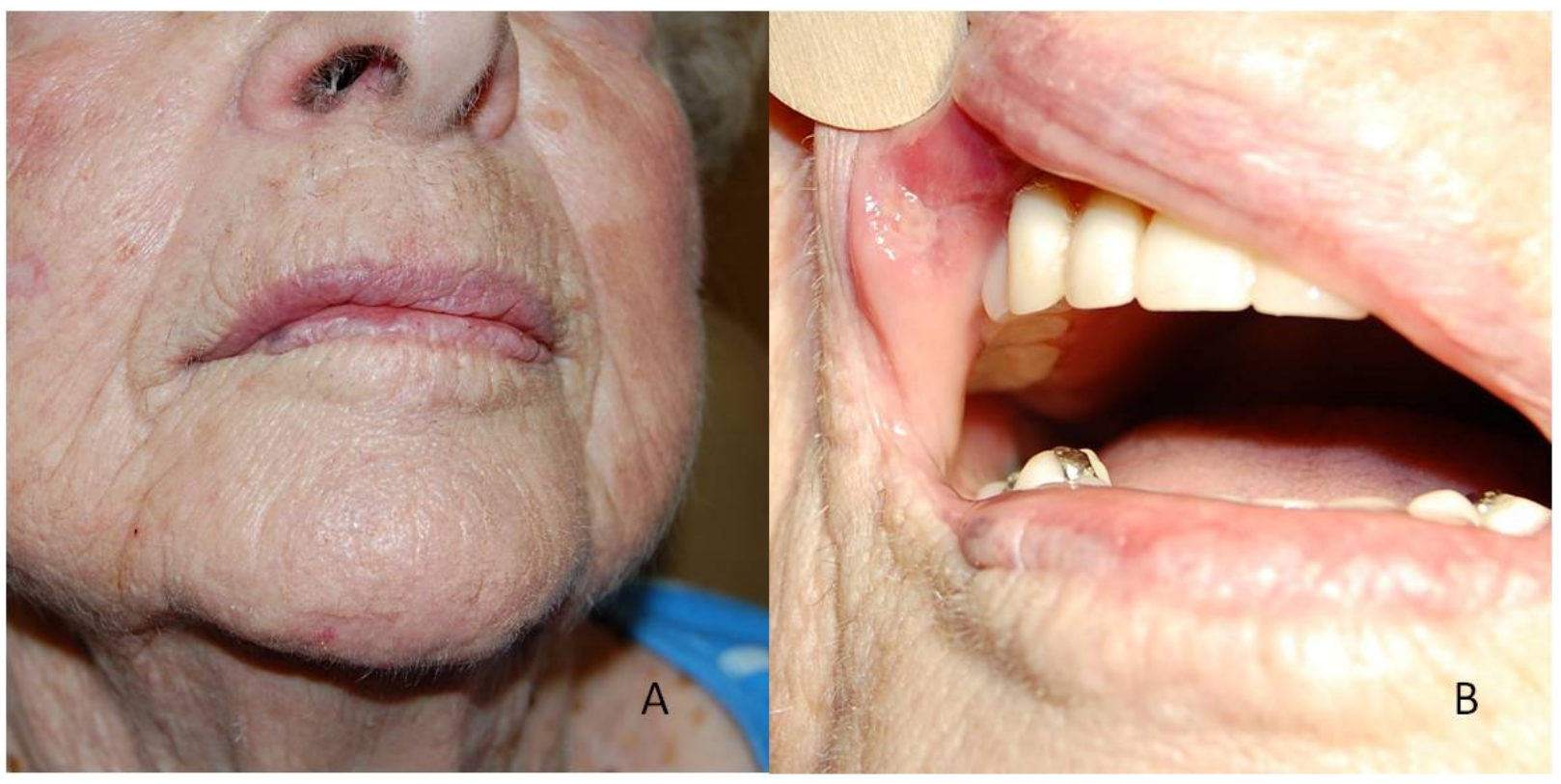

Figure 3. A. Presentation of the patient two weeks after biopsy showing significant resolution in facial swelling. B. Significant spontaneous resolution of the ulcerated lesion of the mucosal aspect of the upper lip two weeks after the biopsy.

\section{Discussion}

ALCL include primary cutaneous and systemic forms ${ }^{[2]}$. Primary cutaneous ALCL (C-ALCL) shows a more indolent disease process with a good prognosis and potential for spontaneous regression ${ }^{[5]}$. It comprises approximately $25 \%$ of cutaneous T-cell lymphomas, second only to mycosis fungoides ${ }^{[6]}$. Patients with C-ALCL are generally older, in their fifth to sixth decades of life on average, and there is a male predominance ${ }^{[7]}$. Skin lesions are most frequent on the trunk, face, extremities and buttocks and patients usually present with solitary or multiple nodules or papules which are often localized ${ }^{[2]}$. Extracutaneous involvement may be seen in 5\%-10\% of patients at presentation ${ }^{[5]}$. The histology shows anaplastic, non-epidermotropic infiltrate of neoplastic large lymphoid cells and often a reactive lymphocytic component at the periphery, especially in ulcerated lesions where eosinophils, neutrophils, and histiocytes may be prominent ${ }^{[2]}$. The anaplastic cells have large irregular and pleomorphic nuclei and abundant pale cytoplasm ${ }^{[7]}$. Reed-Sternberg-like cells and multinucleated giant cells may be seen ${ }^{[5,7]}$. The immunohistochemical profile of C-ALCL shows strong CD30 immunoreactivity in at least $75 \%$ of cells with expression of a T-cell phenotype (CD45RO, CD43) and variable loss of $\mathrm{T}$ cell antigens (CD2, CD3, CD5 or CD7) ${ }^{[7]}$. Cytotoxic granules-associated proteins (TIA1, granzyme B, perforin) may also be expressed ${ }^{[2]}$. Unlike systemic ALCL, these lesions are ALK (-) and epithelial membrane antigen (EMA) negative but usually express the cutaneous lymphocyte antigen $(C L A)^{[2,5]}$. Spontaneous regression has been reported in up to $42 \%$ of patients in some studies ${ }^{[6,7]}$.

Primary systemic ALCL is mainly nodal in origin and is further subdivided into cases that show expression ALK protein, and those that are ALK-negative ${ }^{[2,5]}$. ALK $(+)$ and ALK (-) ALCL- compose $6.5 \%$ and $5.5 \%$ of T-cell lymphomas respectively ${ }^{[5]}$. Significant differences exist between these two categories. The average age of patients with ALK $(+)$ 
ALCL is significantly younger (3rd decade) than those with ALK (-) ALCL (5th-6th decades) ${ }^{[9-11]}$. ALK (+) ALCL often harbor chromosomal translocations, the most common of which is $\mathrm{t}(2 ; 5)(\mathrm{p} 23 ; \mathrm{q} 35)$ translocation ${ }^{[2,5]}$. ALK (-) ALCL lack any definitive cytogenetic abnormalities and have a much poorer prognosis than ALK $(+)$ counterpart ${ }^{[2]}$. Both systemic subtypes have a worse 5-year survival rate than primary C-ALCL [A nearly 80\% 5-year survival rate for ALK $(+), 48 \%$ for ALK (-) versus $90 \%$ for cutaneous ALCL $]^{[2,6,8]}$.

The morphologic features of systemic ALCL are similar to C-ALCL, both containing large anaplastic lymphoid cells growing in a sinusoidal or sheet-like, cohesive pattern ${ }^{[1]}$. "Hallmark cells" or large cells with eccentric, horseshoe- or kidney-shaped nuclei are frequently present ${ }^{[2]}$. By definition, CD30 is strongly expressed in all cases of ALCL (Both the cutaneous and systemic forms). Systemic ALCL can be have a T-cell type, expressing a range of T-cell markers with possible loss of one or more pan T-cell antigens, or of a null cell type, expressing no T-cell markers ${ }^{[2]}$. Regardless of expression of T-cell associated antigens, approximately $90 \%$ of cases show clonal T-cell receptor rearrangement. Cytotoxic granulocytes-associated proteins may be expressed in both systemic and cutaneous ALCL and EBV markers are generally negative ${ }^{[2]}$. Systemic ALCL with expression of CD56 have been shown to have an inferior outcome ${ }^{[10]}$.

The most common chromosomal abnormality associated with ALK (+) ALCL (In 84\% of cases) is the t (2; 5) (p23; q35) reciprocal translocation between the gene encoding for ALK and the gene encoding for NPM, a nucleolar-associated phosphorprotein, on chromosome $2^{[2]}$. The ALK gene encodes a tyrosine kinase receptor which acts as an insulin growth factor receptor ${ }^{[12]}$. Other variant translocations also occur involving the ALK gene and genes on chromosomes ${ }^{[1-3,17,19,22]}$, and the $\mathrm{X}$ chromosome ${ }^{[2]}$. These different translocations result in distinct nuclear and/or cytoplasmic patterns of immunoreactivity with ALK1 antibodies. The ALK protein expression and translocation have also been identified in varying entities other than ALCL including inflammatory myofibroblastic tumors, DLBCL, non-small cell lung cancer, esophageal squamous cell carcinoma, colon carcinoma, breast carcinoma, and neuroblastoma ${ }^{[12-16]}$. Primary cutaneous ALCL and systemic ALK (-) ALCL do not have any recurrent cytogenetic abnormalities ${ }^{[2]}$.

The differential diagnosis of ALCL includes Hodgkin lymphoma (HL), other forms of CD30 (+) T-or B-cell lymphoma with anaplastic morphology, and undifferentiated carcinoma or other malignancies. HL is of particular concern since it shares CD30 immunoreactivity and large atypical cell appearance. HL can be differentiated based on the expression of a variable combination of B-cell antigen (CD20, PAX-5) and CD15 and lack of expression of CD45-the leukocyte common antigen (LCA) ${ }^{[17]}$. Other variants of peripheral T-cell lymphoma can be ruled out based on the limited CD30 expression and lack the hallmark cells ${ }^{[17]}$. Anaplastic forms of DLBCL are rare but should also be considered in the differential diagnosis, and can be ruled out based on the pattern of expression of B-cell associated antigens, and have a distinct pattern of ALK immunoreactivity ${ }^{[2]}$. Undifferentiated carcinoma and melanoma can be identified using cytokeratin and melanoma markers ${ }^{[17]}$.

A search of the literature in the English language in PUBMED identified 11 prior cases of CD30 (+) ALCL involving the oral cavity ${ }^{[18-27]}$. In addition, several early cases were also reported as oral CD30+ ALCL but can be now reclassified into different categories of T- or B-cell lymphomas according to the most recent WHO classification of lymphoma ${ }^{[28-30]}$. Of the 11 reported cases, all were of the T-cell type except for one case with null cell type ${ }^{[27]}$. Including the current case, the average age of the patients was 59.5 years, although a large range was noted (12-88 years). Females comprised 55\% of the patients and males $45 \%$. The lesions appeared in various locations throughout the mouth including both in the soft tissue and in bone. Ulceration was a common presenting feature along with swelling. The clinical presentation of the cases varied widely with some reporting systemic or cutaneous involvement and others with the oral lesions alone. One case was reported as ALK $(+)$, one as ALK $(-)$, and the status of ALK expression was not reported in the remaining cases ${ }^{[24,27]}$. One other case reported spontaneous regression with relapses ${ }^{[24]}$.

Several other entities appear to fall into the spectrum of indolent atypical CD30 $(+)$ oral lymphoproliferative disorders with a potential for spontaneous regression. Some cases of traumatic eosinophilic granuloma-like lesions in the oral cavity 
which have been classified as oral manifestations of CD30 (+) T-cell lymphoproliferative disorder have also been reported ${ }^{[31-33]}$. These cases presented with recurring intraoral lesions that often healed spontaneously after biopsy and were composed of large atypical CD30 (+) cells of a T-cell phenotype with a mixed, eosinophil-rich reactive inflammatory cell infiltrate. None of these patients reported a previous history of cutaneous T-cell lymphoma, although one case developed a cutaneous lesion one year after the first oral ulcer ${ }^{[1-33]}$, and none of these patients developed any systemic manifestations of the oral disease. A similar case was reported that showed EBV positivity in a traumatic eosinophilic granuloma-like lesion with $\mathrm{CD} 30$ and CD3 expression ${ }^{[34]}$. This patient also showed no cutaneous or systemic manifestations.

Current published criteria suggest that lesions resembling C-ALCL in the setting of MF should be classified as transformed $\mathrm{MF}^{[2]}$. However, this definition addresses neither differences in ALK status nor the clonal relationship between the lesions. In the present case, we cannot completely exclude the possibility that this patient's previous cutaneous T-cell lymphoma acquired other genetic aberrations that led to its transformation into ALCL-like process. However, in this case an ALCL-like lesion arose in an anatomically different site from the previous locations of the cutaneous T-cell lymphoma, after a relatively long period of clinical remission. Tissue from the previous biopsy was unavailable to demonstrate the presence or lack of identical clonality. Overall, we favor two distinct processes.

In conclusion, oral manifestations of ALCL represent a spectrum of disease behavior and progression and pose challenges relating to the diagnosis and prognosis. Care should be taken to differentiate between this entity and other similar indolent oral lymphoproliferative disorders which may present with a similar clinical ulcerative appearance and a have potential for spontaneous regression, and thus affecting therapeutic decision making.

\section{Conflict of interest}

The authors declare that there is no conflict of interest statement.

\section{References}

[1] O'Leary H, Savage KJ. The spectrum of peripheral T-cell lymphomas. Curr Opin Hematol 2009;16:292-98. PMid:19509496 http://dx.doi.org/10.1097/MOH.0b013e32832b89a9

[2] Swerdlow SH, Campo E, Harris NL, Jaffe ES, Pileri SA, Stein H, Thiele J, Vardiman JW. WHO Classification of Tumors of Hematopoietic and Lymphoid Tissues. 4th ed. Lyon: IARC:2008.

[3] Lin P, Medeiros LJ. Hematopoietic lesions. In: Diagnostic Surgical Pathology of the Head and Neck. Gnepp DR, editor. 2nd ed. Saunders: Philadelphia, 2009. http://dx.doi.org/10.1016/B978-1-4160-2589-4.00013-9

[4] Neville BW, Damm DD, Allen CM, Bouquot JE. Oral and Maxillofacial Pathology. 3rd ed. St. Louis: Saunders Elsevier. 2009.

[5] Querfeld C, Khan I, Mahon B, Nelson BP, Rosen ST, Evens AM. Primary cutaneous and systemic anaplastic large cell lymphoma: Clinicopathologic aspects and therapeutic options. Oncology 2010;24(7):574-87. PMid:20669794

[6] Bekkenk MW, Geelen FAMJ, van Voorst Vader PC, Heule F, Geerts M-L, van Vloten WA, et al. Primary and secondary cutaneous CD30+ lymphoproliferative disorders: A report from the Dutch cutaneous lymphoma group on the long-term follow-up data of 219 patients and guidelines for diagnosis and treatment. Blood 2000;95(12):3653-61. PMid:10845893

[7] Kempf W, Burg G. Lymphoid, leukemic, and other cellular infiltrates. In: Dermatopathology. Barnhill, RL editor. 3rd edition. New York: McGraw Hill. 2010.

[8] Woo DK, Jones CR, Vanoil-Storz MN, Kohler S, Reddy S, Advani R, et al. Prognostic factors in primary cutaneous anaplastic large cell lymphoma. Arch Dermatol 2009;145(6):667-74. PMid:19528422 http://dx.doi.org/10.1001/archdermatol.2009.74

[9] Falini B, Pileri S, Zinzani PL, Carbone A, Zagonel V, Wolf-Peeters C, et al. ALK+ lymphoma: Clinic-pathological findings and outcome. Blood 1999;93(8):2697-706. PMid:10194450

[10] Suzuki R, Kagami Y, Takeuchi K, Kami M, Okamoto M, Ichinohasama R, et al. Prognostic significance of CD56 expression for ALK-positive and ALK-negative anaplastic large-cell lymphoma of T/null cell phenotype. Blood 2000;96(9):2993-3000.

PMid:11049976 
[11] TenBerge RL, DeBruin PC, Oudejans JJ, Ossenkoppele GJ, Van Der Valk P, Meijer CJLM. ALK-negative anaplastic large-cell lymphoma demonstrates similar poor prognosis to peripheral T-cell lymphoma, unspecified. Histopathology 2003;43(5):462-69. PMid:14636272 http://dx.doi.org/10.1046/j.1365-2559.2003.01726.x

[12] Barreca A, Lasorsa E, Riera L, Machiorlatti R, Piva R, Ponzoni M, et al. Anaplastic lymphoma kinase in human cancer. J of Mol Endocrinol 2011;47:11-23. PMid:21502284 http://dx.doi.org/10.1530/JME-11-0004

[13] Arber DA, Sun LH, Weiss LM. Detection of the $\mathrm{(2;5)} \mathrm{(p23;} \mathrm{q35)} \mathrm{chromosomal} \mathrm{translocation} \mathrm{in} \mathrm{large} \mathrm{B-cell} \mathrm{lymphomas} \mathrm{other} \mathrm{than}$ anaplastic large cell lymphoma. Hum Pathol 1996;27:590-94. http://dx.doi.org/10.1016/S0046-8177(96)90167-7

[14] Lin E, Guan Y, Soriano R, Rivers CS, Mohan S, Pandita A, et al. Exon array profiling detects EML4-ALK fusion in breast, colorectal, and non-small cell lung cancers. Mol Cancer Res 2009;7:1466-76. PMid:19737969 http://dx.doi.org/10.1158/1541-7786.MCR-08-0522

[15] Jazii FR, Najafi Z, Malekzadeh R, Conrads TP, Ziaee AA, Abnet C, et al. Identification of squamous cell carcinoma associated proteins by proteomics and loss of $\beta$ tropomyosin expression in esophageal cancer. World J Gastroenterol 2006;12:7104-12. PMid:17131471

[16] Kelleher FC, McDermott R. The emerging pathogenic and therapeutic importance of the anaplastic lymphoma kinase gene. Eur J Cancer 2010;46:2357-68. PMid:20451371 http://dx.doi.org/10.1016/j.ejca.2010.04.006

[17] Ioachim HL, Medeiros LJ. Ioachim's Lymph Node Pathology. 4th ed. Philadelphia: Lippincott Williams and Wilkins:2009.

[18] Takahashi H, Fujita S, Okabe H, Tsuda N, Tezuka F. Immunophenotypic analysis of extranodal non-Hodgkin's lymphomas in the oral cavity. Path Res Pract 1993;189:300-11. http://dx.doi.org/10.1016/S0344-0338(11)80514-5

[19] Willard CC, Ross RD, Hobbs TJ, Auclair PL. Primary anaplastic large cell (Ki-1 positive) lymphoma of the mandible as the initial manifestation of acquired immunodeficiency syndrome in a pediatric patient. Oral Surg Oral Med Oral Pathol Oral Radiol Endod 1995:80:67-70. http://dx.doi.org/10.1016/S1079-2104(95)80018-2

[20] Rosenberg A, Biesma DH, Sie-Go DMDS, Slootweg PJ. Primary extranodal CD30-positive T-cell non-Hodgkin's lymphoma of the oral mucosa. Report of two cases. Int J Oral Maxillofac Surg 1996;25:57-59.

http://dx.doi.org/10.1016/S0901-5027(96)80013-0

[21] Papadimitriou JC, Abruzzo LV, Bourquin PM, Drachenberg CB. Correlation of light microscopic, immunocytochemical and ultrastructural cytomorphology of anaplastic large cell lymphoma, an activated lymphocyte phenotype. Acta Cytol 1996;40:1283-88. PMid:8960041 http://dx.doi.org/10.1159/000334022

[22] Chim CS, Chan ACL, Raymond L. Primary CD30-positive anaplastic large cell lymphoma of the lip. Oral Oncol 1998;34:313-15. http://dx.doi.org/10.1016/S1368-8375(98)80014-6

[23] Born S, Gaber G, Willegeroth K, Wagner U, Haneke E, Marsch WC. Metastasising malignant lymphoma mimicking necrotizing and hyperplastic gingivostomatitis. Eur J Dermatol 1999;9(7):569-73. PMid:10523740

[24] Notani K, Shindoh M, Takami T, Yamazaki Y, Kohgo T, Fukuda H. Anaplastic large cell lymphoma (ALCL) in the oral mucosa with repeating recurrence and spontaneous regression of ulceration: Report of a case. Oral Med Pathol 2002;7:79-82. http://dx.doi.org/10.3353/omp.7.79

[25] Matsumoto N, Ohki H, Mukae S, Amano Y, Harada D, Nishimura S, Komiyama K. Anaplastic large cell lymphoma in gingival: Case report and literature review. Oral Surg Oral Med Oral Pathol Oral Radiol Endod 2008;106:e29-e34. PMid:18656392 http://dx.doi.org/10.1016/j.tripleo.2008.05.037

[26] Villa A, Mariani U, Villa F. T-cell lymphoma of the oral cavity: A case report. Aust Dent J 2010;55:203-206. PMid:20604765 http://dx.doi.org/10.1111/j.1834-7819.2010.01212.x

[27] Fatusi O, Gbolahan O, Owotade R, Rotimi O, Edward S, Adelusola K. Anaplastic large cell lymphoma: Case report and literature review. J Oral Maxillofac Surg 2010;68:884-88. PMid:19954878 http://dx.doi.org/10.1016/j.joms.2009.04.084

[28] Langford A, Dienemann D, Schurman D, Pohle HD, Pauli G, Stein H, et al. Oral manifestations of AIDS-associated non-Hodgkin's lymphomas. Int J Oral Maxillofac Surg 1991;20:136-41. http://dx.doi.org/10.1016/S0901-5027(05)80002-5

[29] Hicks MJ, Flaitz CM, Nichols CM, Luna MA, Gresik MV. Intraoral presentation of anaplastic large-cell Ki-1 lymphoma in association with HIV infection. Oral Surg Oral Med Oral Pathol Oral Radiol Endod 1993;76:73-81.

[30] Savarrio L, Gibson J, Dunlop DJ, O’Rourke N, Fitzsimmons EJ. Spontaneous regression of an anaplastic large cell lymphoma in the oral cavity: First reported case and review of the literature. Oral Oncol 1999:35:609-13. http://dx.doi.org/10.1016/S1368-8375(99)00034-2

[31] Alobeid B, Pan L-X, Milligan L, Budel L, Frizzera G. Eosinophil-rich CD30+ lymphoproliferative disorder of the oral mucosa. A form of "traumatic eosinophilic granuloma". Am J Clin Pathol 2004;121:43-50. PMid:14750239 http://dx.doi.org/10.1309/JQFXPND6DBLF6B9U 
[32] Agarwal M, Shenjere P, Blewitt RW, Hall G, Sloan P, Pigadas N, et al. CD30-positive T-cell lymphoproliferative disorder of the oral mucosa-an indolent lesion: Report of 4 cases. Int J Surg Pathol 2008;16(3):286-90. PMid:18387994 http://dx.doi.org/10.1177/1066896907313755

[33] Ficarra G, Prignano F, Romagnoli P. Traumatic eosinophilic granuloma of the oral mucosa: A CD30+ (Ki-1) lymphoproliferative disorder? Oral Oncol 1997;33(5):375-79. http://dx.doi.org/10.1016/S1368-8375(97)00014-6

[34] Abdel-Naser MB, Tsatsou F, Hippe S, Knolle J, Anagnostopoulos I, Stein H, et al. Oral eosinophilic ulcer, an Epstein-Barr Virus-Associated CD30+ lymphoproliferation? Dermatology 2011;222:113-18. PMid:21464557

http://dx.doi.org/10.1159/000325460 